\title{
IMPLIKASI YURIDIS TERHADAP ISTRI DAN ANAK DARI PERKAWINAN KEDUA/KETIGA/KEEMPAT PEGAWAI NEGERI SIPIL YANG TIDAK DICATATKAN DITINJAU DARI UU NOMOR 1 TAHUN 1974 DAN PP NOMOR 45 TAHUN 1990 PERUBAHAN ATAS PP NOMOR 10 TAHUN 1983
}

\author{
Novita Setyoningrum, \\ Dosen Fakultas Hukum Universitas Islam Balitar, \\ E-mail: davafadil22@gmail.com
}

\begin{abstract}
ABSTRAKSI
Perkawinan merupakan peristiwa penting dalam kehidupan manusia. Dimana perkawinan adalah ikatan lahir dan batin antara seorang pria dan seorang wanita untuk menjadi suami istri yang bertujuan membentuk keluarga bahagia kekal abadi berdasarkan Ketuhanan Yang Maha Esa. Tidak terkecuali Pegawai Negeri Sipil. Pada dasarnya azas perkawinan di Indonesia adalah azas monogami. Meskipun poligami tidak dilarang selama memenuhi syarat dan ketentuan yang berlaku sesuai Undang-Undang Nomor 1 Tahun 1974. Khusus PNS ada aturan tersendiri mengenai poligami yang diatur dalam PP Nomor 45 Tahun 1990 juncto PP Nomor 10 Tahun 1983. Yang mana PNS (Pria) yang berkeinginan beristri lebih dari satu orang harus mendapatkan izin dari Pejabat. Dan jika dalam jangka satu (1) tahun perkawinan yang kedua/ketiga/keempat tersebut tidak dilaporkan akan mendapatkan sanksi. Sanksi untuk pelanggaran PNS telah diatur dalam PP Nomor 53 Tahun 2010 juncto PP Nomor 30 Tahun 1980. Karena dianggap sulit dan berbelit pada akhirnya banyak PNS yang melakukan perkawinan poligami secara siri/tidak dicatatkan. Dari sinilah akan timbul implikasi hukum terhadap istri dan anak dari perkawinan poligami yang tidak dicatatkan.

Penelitian ini menggunakan metode Penelitian ini menggunakan metode yuridis normatif. Penelitian yuridis normatif adalah penelitian hukum yang dilakukan dengan cara meneliti sumber pustaka dan pada data sekunder saja. ${ }^{1}$ Yang berupa norma hukum tertulis. Metode ini sangat berkaitan dengan pendekatan masalah, spesifikasi penelitian dan jenis bahan hukum yang dikumpulkan dalam penelitian yang dilakukan. Penelitian ini adalah penelitian deskriptif analitis dimana dalam penelitian ini dilakukan untuk memberikan gambaran yang lebih detail mengenai suatu gejala atau fenomena.

Harapan yang ingin disampaikan peneliti dalam penelitian ini adalah PNS pria yang akan melakukan perkawinan poligami hendaknya dilakukan sesuai aturan dan ketentuan yang berlaku berdasarkan PP Nomor 45 Tahun 1990 juncto PP Nomor 10 Tahun 1983. Agar peningkatan perkawinan poligami PNS Pria yang tidak dicatatkan, dapat ditekan jumlahnya. Dimana dalam perkawinan tersebut kedudukan istri dan anak menjadi tidak jelas dan tidak mendapatkan perlindungan secara hukum dari Negara.
\end{abstract}

Kata Kunci: Kedudukan Istri dan Anak, Perkawinan Poligami, PNS (Pria), Yang tidak dicatatkan. 


\begin{abstract}
Every people wants their marriage happy, and get long lasting relationship. They wants their couple always love, care, and be faithfull man. But it may be not everlasting. Marriagae Indonesian principle actually is monogamy. Althought polygamy is able to do in Indonesia. But in real, there are many people espessialy male PNS (government labour). They get polygamy marriage with unregistered marriage.

In this thesis research writer with normatif's judicial formally that did by analyzes library material or secondary data over and above see society case.

According to Islamic Law, whatever from and marriage model ; along have accomplished on good terms and its requisite therefore that marriage is reputed temporary legitimate terminological Indonesia conjugal rights besides religions terminological validity and its trust, a marriage has legal power if on record base legislation regulation which is at KUA divides Moslem and KCS divides non Moslem

Marriage bad impact siri constitusi effect of grasp that don't comprehensive to marriage and frail law its envorcement sentences to protect victims. Obiviously govermment shortly amends all conjugal rights product be adjusted with rill's condution society that protects all faction and behalf
\end{abstract}

Key word: Implication Yuridis, Wife and The Children of Polygamy Unregistered, Male Government Labour (PNS).

\title{
PENDAHULUAN
}

\section{Latar Belakang}

Perkawinan merupakan peristiwa yang penuh makna dalam kehidupan setiap manusia. Berdasarkan Pasal 1 Undang-Undang Nomor 1 Tahun 1974 tentang Perkawinan menyebutkan bahwa: "Perkawinan merupakan ikatan lahir dan batin seorang pria dan wanita untuk menjadi suami istr yang bertujuan membentuk keluarga bahagia kekal abadi berdasarkan Ketuhanan Yang Maha Esa." 2 Berdasarkan bunyi pasal diatas pada dasarnya perkawinan di Indonesia adalah berazaskan monogami. Ini dapat kita lihat dalam Pasal 3 ayat (1) yang menyatakan bahwa: "Pada azasnya seorang pria hanya boleh boleh menikahi seorang istri." 3 Meskipun menganut azas perkawinan secara monogamy, tetapi beristri lebih dari satu orang tidak dilarang, selama melaksanakan ketentuan dan syarat tentang poligami yang diatur dalam Pasal 3 ayat (2): "Pengadilan dapat memberi izin kepada seorang suami untuk beristri lebih dari satu orang apabila dikehendaki oleh pihak-pihak yang bersangkutan."4 Pengadilan hanya memberikan izin kepada seorang suami yang akan beristri lebih dari seorang apabila:

1. Istri tidak dapat menjalankan kewajibannya sebagai istri;

2. Istri mendapat cacat badan yang tidak dapat disembuhkan;

3. Istri tidak dapat melahirkan keturunan. ${ }^{5}$ Pasal 4 ayat (2) UUP Nomor 1 Tahun 1974.

Untuk Pegawai Negeri Sipil Pria yang akan beristri lebih dari seorang ada aturannya sendiri yang termaktub dalam PP Nomor 45 Tahun 1990 Perubahan Atas PP Nomor 10 Tahun 1980 Pasal 4 ayat (1) yang menyebutkan bahwa: “Pegawai Negeri Sipil yang akan

\footnotetext{
${ }^{2}$ Grahamedia Press, Undang-Undang Republik Indonesia Nomor 1 Tahun 1974 Tentang Perkawinan, (Jakarta: Grahamedia Press, 2014), hlm. 2.

${ }^{3}$ Ibid

${ }^{4}$ Ibid

${ }^{5}$ Ibid
} 
beristri lebih dari seorang wajib memperoleh izin terlbih dahulu dari Pejabat."6 Dan jika dalam waktu selambat-lambatnya satu tahun terhitung sejak perkawinan tersebut dilaksanakan dijatuhi hukuman disiplin berat berdasarkan PP Nomor 53 Tahun 2010 Perubahan Atas PP Nomor 30 Tahun 1980 tentang Peraturan Disiplin Pegawai Negeri Sipil. Karena harus melewati tahap-tahapan yang dirasa rumit dan berbelit, banyak Pegawai Sipil Pria yang akan beristri lebih dari seorang memilih untuk melakukan perkawinan kedua/ketiga/keempat mereka secara tidak dicatatkan/siri. Sedangkan hukum perkawinan Negara Indonesia tidak mengakui adanya perkawinan yang tidak dicatatkan. Sehingga secara hukum perkawinan tersebut dianggap tidak pernah ada meskipun menurut hukum Islam perkawinan dianggap sah apabila sudah memenuhi rukun dan syarat perkawinan secara Islam. Karena hukum Negara tidak mengakui perkawinan tersebut maka perlindungan hukum terhadap istri dan anak dari perkawinan kedua/ketiga/keempat tersebut diatas juga tidak ada. Mirisnya lagi anak yang dilahirkan dalam perkawinan yang tidak dicatatkan akan menyandang status anak luar kawin dimana telah disebutkan dalam Pasal 43 ayat (1) UUP Nomor 1 Tahun 1974 bahwa: "Anak yang diilahirkan diluar perkawinan hanya mempunyai hubungan perdata dengan ibunya dan keluarga ibunya."7

\section{Rumusan Masalah}

1. Apakah implikasi yuridis terhadap istri dan anak hasil perkawinan kedua/ketiga/keempat Pegawai Negeri Sipil yang tidak dicatatkan?

2. Bagaimanakah perlindungan hukum terhadap istri dan anak hasil perkawinan kedua/ketiga/keempat Pegawai Negeri Sipil yang tidak dicatatkan?

\section{PEMBAHASAN}

\section{TINJAUAN UMUM TENTANG PERKAWINAN POLIGAMI PNS PRIA}

\subsection{Pengertian Pegawai Negeri Sipil (PNS)}

Berdasarkan Undang-Undang Nomor 43 Tahun 1990 Perubahan Atas PP Nomor 8 Tahun 1974 tentang Pokok-Pokok Kepegawaian. Pegawai Negeri Sipil adalah "Setiap Warga Negara Republik Indonesia yang memenuhi syarat yang ditentukan, diangkat oleh Pejabat berwenang dan diserahi tugas suatu jabatan negeri atau diserahi tugas Negara lainnya dan digaji berdasarkan peraturan perundang-undangan yang berlaku."

\subsection{Syarat Dan Ketentuan Bagi PNS Pria Yang Akan Beristri Lebih Dari Satu Orang (Poligami)}

Pegawai Negeri Sipil Pria yang akan beristri lebih dari satu orang sudah diatur dalam PP Nomor 45 Tahun 1990 Perubahan Atas PP Nomor 10 Tahun 1983. Antara PP Nomor 10 Tahun 1983 dengan PP Nomor 45 Tahun 1990 yang sama-sama mengatur tentang Izin Perkawinan Dan Perceraian Bagi Pegawai Negeri Sipil mempunyai hubungan yang saling mengisi dan saling melengkapi diantara keduanya. Pasal 16 PP Nomor 10 Tahun 1983 mengatur tentang ancaman hukuman, yang mana "Pegawai Negeri Sipil yang melanggar ketentuan Pasal 4 ayat (1), ayat (2), ayat (3) dijatuhi hukuman disiplin berupa pemberhentian dengan hormat tidak atas permintaan sendiri sebagai Pegawai Negeri Sipil."

\footnotetext{
${ }^{6}$ Ibid, hlm. 120-121.

${ }^{7}$ Ibid hlm. 13
} 
Dan disempurnakan lagi dalam PP Nomor 45 Tahun 1990 Pasal 15 ayat (1) yang mengatakan bahwa: "Pegawai Negeri Sipil yang melanggar salah satu atau lebih kewajiban/ketentuan Pasal 2 ayat (1), ayat (2), Pasal 3 ayat (1), Pasal 4 ayat (1) dan tidak melaporkan perkawinannya kedua/ketiga/keempat dalam jangka waktu selambatlambatnya satu tahun terhitung sejak perkawinan tersebut dilangsungkan dijatuhi hukuman disiplin berat berdasarkan PP Nomor 30 Tahun 1980 tentang Peraturan Disiplin Pegawai Negeri Sipil." PP Nomor 30 Tahun 1980 tentang Peraturan Disiplin Pegawai Negeri Sipil sudah tidak sesuai dengan kebutuhan dan perkembangan keadaan, maka Peraturan Pemerintah ini diperbarui dengan PP Nomor 53 Tahun 2010.

Adapun jenis hukuman disiplin berat sebagaimana dimaksud dalam PP Nomor 53 Tahun 2010 Pasal 7 ayat (4) huruf a, b, c, d, e. Diantaranya adalah:

a. Penurunan pangkat setingkat lebih rendah selama (3) tahun;

b. Pemindahan dalam rangka penurunan jabatan setingkat lebih rendah;

c. Pembebasan dari jabatan;

d. Pemberhentian dengan hormat tidak atas permintaan sendiri sebagai Pegawai Negeri Sipil; dan

e. Pemberhentian tidak dengan hormat sebagai Pegawai Negeri Sipil.

1.3 Izin Perkawinan Lebih Dari Satu Orang Istri Bagi Masyarakat Sipil (Pria) Ditinjau Dari Undang-Undang Nomor 1 Tahun 1974 Tentang Perkawinan.

Perkawinan lebih dari satu orang istri tidak dilarang bahkan diberikan izin oleh Undang-Undang dengan syarat dan ketentuan yang berlaku, diantaranya:

1. Disebutkan dalam Undang-Undang Nomor 1 Tahun 1974 Tentang Perkawinan Pasal 3 ayat (2) : "Pengadilan dapat memberikan izin kepada seorang suami untuk beristri lebih dari seorang apabila dikehendaki oleh pihak-pihak yang bersangkutan."

2. Pasal 4 ayat (1) Undang-Undang Nomor 1 Tahun 1974 menyebutkan bahwa: "Dalam hal suami akan beristri lebih dari seorang, wajib mengajukan permohonan kepada Pengadilan didaerah tempat tinggalnya;

3. Pasal 4 ayat (2) Undang-Undang Nomor 1 Tahun 1974, "Pengadilan hanya memberikan izin kepada seorang suami yang akan beristri lebih dari satu orang apabila:

a. Istri tidak dapat menjalankan kewajibannya sebagai istri (kebutuhan lahir dan batin);

b. Istri mendapat cacat badan atau penyakit yang tidak dapat disembuhkan;

c. Istri tidak dapat melahirkan keturunan.

4. Pada Pasal 5 ayat (1) huruf a, b, c, disebutkan bahwa: "Untuk mengajukan permohonan kepada Pengadilan, maka harus dipenuhi syarat-syarat dibawah ini:

a. Adanya persetujuan dari istri/istri-istri;

b. Adanya kepastian bahwa suami mampu menjamin keperluan hidup istri dan anak-anak mereka;

c. Adanya jaminan suami akan berlaku adil terhadap istri-istri dan anak-anak mereka.

\subsection{Izin Perkawinan Lebih Dari Satu Orang Istri Bagi Pegawai Negeri Sipi} Pria Ditinjau Dari PP Nomor 10 Tahun 1983 Dan PP Nomor 45 Tahun 1990 
Pada Pasal 4 ayat (1) menyatakan bahwa: "Pegawai Negeri Sipil Pria yang akan beristri lebih dari satu orang wajib memperoleh izin lebih dahulu dari Pejabat." Permintaan izin kepada Pejabat harus diajukan secara tertulis. Dalam surat permintaan izin harus dicantumkan alasan yang lengkap yang mendasari permintaan izin untuk beristri lebih dari seorang. Izin untuk beristri lebih dari satu orang hanya dapat diberikan oleh Pejabat apabila memenuhi sekurang-kurangnya satu syarat alternatif dan ketiga syarat kumulatif.

Adapun syarat Alternatif berdasar Pasal 10 ayat (2) PP Nomor 10 Tahun 1983 yaitu:

1. Istri tidak dapat menjalankan kewajibannya sebagai istri;

2. stri mendapat cacat badan atau penyakit yang tidak dapat disembuhkan;

3. Istri tidak dapat melahirkan keturunan.

Dan syarat kumulatifnya adalah sebagai berikut:

a. Ada persetujuan tertulis dari istri;

b. PNS pria mempunyai penghasilan yang cukup untuk membiayai lebih dari satu orang istri dan anak-anaknya yang dibuktikan dengan surat keterangan pajak penghasilan;

c. Ada jaminan tertulis dari PNS yang bersangkutan bahwa ia akan berlaku adil terhadap istri dan anak-anaknya.

Pejabat yang menerima permintaan izin untuk beristri lebih dari satu orang wajib memperhatikan dengan seksama alasan-alasan yang dikemukakan dalam surat permintaan izin dan pertimbangan dari atasan PNS yang bersangkutan. Apabila alasan-alasan dan syarat-syarat yang dikemukakan dalam permintaan izin kurang meyakinkan maka Pejabat harus meminta keterangan tambahn dari istri PNS yang mengajukan permintaan izin.

Izin untuk beristri lebih dari seorang tidak diberikan oleh Pejabat apabila:

a. Bertentangan dengan ajaran/peraturan agama yang dianut PNS yang bersangkutan;

b. Tidak memenuhi syarat alternative dan kumulatif;

c. Bertentangan dengan peraturan perundang-undangan yang berlaku;

d. Alasan yang dikemukakan bertentangan dengan akal sehat;

e. kemungkinan mengganggu pelaksanaan tugas kedinasan;

f. Setiap atasan yang menerima permintaan izin dari Pegawai Negeri Sipil dalam lingkungannya untuk beristri lebih dari seorang wajib memberikan pertimbangan dan meneruskannya kepada pejabat melalui saluran hierarki dalam jangka waktu selambat-lambatnya tiga (3) bulan terhitung mulai tanggal ia menerima surat izin yang dimaksud.

\section{TINJAUAN UMUM PERKAWINAN YANG TIDAK DICATATKAN (SIRI) MENURUT HUKUM ISLAM}

\subsection{Pengertian Perkawinan Siri}

Perkawinan Siri dalam pandangan Islam adalah perkawinan yang dilakukan untuk memenuhi syarat wajib sahnya akad nikah. Yang terdiri dari:

a. Adanya calon pengantin mempelai pria dan mempelai wanita;

b. Adanya wali pengantin wanita;

c. Dua orang saksi;

d. Ijab; dan 
e. Qobul. ${ }^{8}$

Syarat-syarat sahnya perkawinan tersebut disebut dengan rukun atau syarat wajib nikah. Selain syarat wajib nikah ada sebutan sebagai sunah nikah, diantaranya adalah sebagai berikut:

a. Khutbah Nikah;

b. Pengumuman Perkawinan/ Walimah;

c. Adanya Mas Kawin;

d. Adanya Mahar.

Dengan demikian dalam proses perkawinan siri, yang dilakukan hanya rukun dan syarat perkawinan saja tetapi sunah perkawinannya belum dilakukan. ${ }^{9}$

Karena tidak melakukan sunah perkawinan yang salah satu diantaranya adalah pengumuman perkawinan/walimah maka perkawinan ini dimaknai dengan keadaan sunyi atau rahasia atau siri. Dalam perkembangannya di kalangan masyarakat Islam berpendapat bahwa perkawinan siri merupakan perkawinan yang sah menurut agama Islam karena dianggap telah memenuhi rukun dan syarat perkawinan.

\subsection{Praktek Perkawinan Siri Di Indonesia}

Praktek perkawinan siri makin marak dilakukan di masyarakat Indonesia. Perkawinan siri merupakan perkawinan yang hanya berdasarkan tata cara pada agama dan kepercayaan serta adat istiadat tanpa dilakukan dihadapan, dicatatkan pada pegawai pencatat nikah, seperti yang telah diatur dalam Undang-Undang Nomor 1 tahun 1974 tentang perkawinan Pasal 2 ayat (1) yang mana: "Perkawinan adalah sah apabila dilakukan menurut hukum masing-masing agamanya dan kepercayaannya itu." dan ayat (2) menyatakan bahwa: "Tiap-tiap perkawinan dicatat menurut peraturan perundang-undangan yang berlaku." Kompilasi Hukum Islam (KHI) Pasal 5 ayat (1), Pasal 6 ayat (2), Pasal 7 ayat (1) dan dalam KUHPerdata Pasal 100.

Adapun perkawinan siri (perkawinan yang tidak dicatatkan) di Indonesia dimaknai dengan perkawinan yang dilakukan oleh wali nikah atau wakil wali yang disaksikan oleh para saksi, tetapi tidak dilakukan dihadapan, petugas pencatat nikah, di Kantor Urusan Agama (KUA) untuk umat muslim dan Kantor Catatan Sipil untuk umat non muslim.

\subsection{Pelaku Perkawinan Siri dan Faktor Penyebab Perkawinan Siri di Indoneisa}

1. Masyarakat Umum/masyarakat sipil:

Faktor Penyebab Perkawinan Siri yang dilakukan masyarakat umum/masyarakat sipil:

a. Tanpa adanya wali dari pihak calon mempelai wanita, karena tidak disetujui oleh pihak wali wanita, atau tidak bisa menghadirkan wali dari pihak wanita ;

b. Karena sudah bertunangan, pihak keluarga dari pihak calon mempelai pria dan calon mempelai wanita sepakat untuk menikahkan kedua anaknya tersebut secara siri, dengan alasan kedua calon mempelai masih melakukan pendidikan, kuliah, atau ikatan dinas dan untuk menghindari perzinahan, keluarga merasa lebih tenang meskipun hanya menikah secara siri, karena keluarga berkeyakinan bahwa perkawinan siri sudah sah menurut syar'i agama Islam dan terhindar dari perbuatan zina;

\footnotetext{
${ }^{8}$ http://id.m.wikipedia.org.

${ }^{9}$ Aep Saepullah, Serial Fiqh D, Munakahat.
} 
c. Sulitnya mendapatkan izin dari istri pertama untuk melakukan perkawinan lebih dari seorang istri (poligami). Akhirnya melakukan perkawinan siri adalah jalan terbaik dan termudah untuk mengatasi permasalahan tersebut;

d. Banyaknya syarat-syarat yang harus dipenuhi untuk mendapatkan izin melakukan perkawinan lebih dari satu orang istri (poligami) dari Pengadilan. Pengadilan Agama untuk masyarakat muslim dan Pengadilan Negeri untuk masyarakat nonmuslim;

e. Karena calon mempelai wanita hamil diluar nikah;

2 Pegawai Negeri Sipil (PNS) Pria:

Faktor Penyebab Perkawinan Siri Yang Dilakukan Pegawai Negeri Sipil (PNS) Pria:

a. Untuk menghindari prosedur administratif yang berbelit-belit yaitu setiap PNS Pria yang akan beristri lebih dari seorang wajib memperoleh izin dari pejabat, Pasal 4 ayat (1) PP Nomor 45 Tahun 1990 Perubahan Atas PP Nomor 10 Tahun 1983;

b. Untuk menghapus jejak agar tidak diketahui oleh istri pertama, karena untuk melakukan perkawinan lebih dari satu orang istri tetap harus mendapatkan izin dan persetujuan dari istri pertama, atau istri-istri sebelumnya.

\subsection{Perkawinan Siri dan Pentingnya Pencatatan Perkawinan}

Hukum Perkawinan Siri dan Pencatatan Perkawinan harus bersumber pada ketentuan Perkawinan menurut Hukum Islam dan sejarah lahirnya Undang-Undang dan Hukum Positif Negara yang mengatur tentang Perkawinan. ${ }^{10}$ Hakekat Perkawinan dalam Hukum Islam telah dianggap sah apabila telah terpenuhi rukun dan syarat sahnya Perkawinan. Hal inilah yang menjadi dasar banyaknya umat muslim Indonesia yang melakukan perkawinan secara agama saja dan tidak dicatatkan kepada Pegawai Pencatat Nikah. Pencatatan Perkawinan merupakan ketentuan baru yang tidak terdapat dalam kitab-kitab fiqih baru. ${ }^{11}$ Pencatatan Perkawinan dapat digunakan sebagai alat bukti telah terjadi peristiwa hukum yaitu perkawinan dimana pada kelanjutannya dapat menimbulkan suatu akibat hukum, dan ini melibatkan aparat Negara dalam pelaksanaan perkawinanyang mana ini merupakan kepanjang tangan Negara dalam melakukan pengawasan. ${ }^{12}$ Pencatatan Perkawinan ini bagi umat Islam adalah mengandung banyak manfaat, berfungsi supaya tertib administratif dan mengurangi kekacauan. Selain diatur dalam Undang-Undang Nomor 1 tahun 1974 Tentang Perkawinan Pasal 2 ayat (2), Kompilasi Hukum Islam (KHI), Pasal 5 ayat (1), Pasal 6 ayat (2), Pasal 7 ayat (1) dan KUHPerdata Pasal 100.

Menurut Peneliti, perkawinan siri adalah sah sepanjang telah memenuhi rukun dan syarat sahnya perkawinan tetapi pada hakekatnya perkawinan yang tidak dicatatkan sesuai peraturan perundang-undangan Undang-Undang Nomor 1 Tahun 1974 tentang perkawinan tidak merupakan suatu pelanggaran terhadap Undang-Undang tetapi hanyalah suatu pelanggaran administratif. Karena hanya perkawinan yang dilakukan dan dicatatkan dihadapan Pegawai Pencatat Nikah yang dianggap sah dan diakui keabsahanya di mata hukum positif Negara Indonesia.

\footnotetext{
${ }^{10}$ Amrullah Ahmad, Dimensi Hukum Islam dan Sistem Hukum Nasional, (Jakarta: Gema Insani Press, 1996) hlm. 131.

${ }^{11}$ Abdul Gani Abdullah, Tinjauan Hukum Terhadap Perkawinan Di Bawah Tangan, (Jakarta, Juli 1995)

${ }^{12}$ Ibid hlm. 58.
} 


\subsection{Implikasi Yuridis Terhadap Istri Hasil Perkawinan Kedua/Ketiga/Keempat Pegawai Negri Sipil Yang Tidak Dicatatkan}

Menurut Hukum Islam, istilah perkawinan berasal dari Arab yaitu An-Nikah dimana ada tiga pendapat ulama figh terkemuka yang mendefinisikan Nikah antara lain sebagai berikut:

a. Mazdhab Al-Hanafiyah

"Akad adalah mempunyai hak untuk melakukan hubungan seksual dengan seorang wanita yang tidak berhalangan untuk dinikahi secara syar'i."

b. Mazhab-Malikiyah

"Akad yang halal untuk melakukan hubungan seksual dengan wanita yang bukan muhrim, majusi, bukan budak, ahli kitab dengan shighah."

c. Mahzhab Asy-Syafi'iyah

"Akad membolehkan hubungan seksual dengan lafadz nikah."

Dilihat dari pendapat-pendapat ahli figh diatas, jelas terlihat bahwa implikasi yuridis dari suatu perkawinan yang sah menurut Hukum Islam adalah sebagai berikut:

1. Perkawinan yang dilakukan, adalah sah menurut hukum Islam selamaterpenuhi syarat dan rukun sahnya perkawinan seperti telah dijelaskan olehpeneliti pada bagian atas penelitian ini;

2. Halal melakukan hubungan seksual diantara suami dan istri;

3. Mas Kawin (mahar) yang diberikan menjadi milik istri;

4. Lahirnya peristiwa hukum berupa perkawinan yang menimbulkan suatuakibat hukum dimana akan ada hak dan kewajiban diantara suami dan istri;

Menurut penulis, perkawinan yang dilakukan menurut hukum Islam (Perkawinan Siri) atau yang tidak dicatatkan adalah sah selama memenuhi rukun dan syarat perkawinan secara syar'i dan tidak melanggar hukum Negara tetapi banyak menimbulkan dampak negatif terhadap istri dan anak yang dilahirkan, jika terjadi perceraian. Dampak negatif yang timbul dari perkawinan yang tidak dicatatkan adalah adanya dua kepentingan yang saling bergesekan dan berbeda. Yaitu perbedaan kepentingan diantara para pelaku perkawinan yang tidak mau mencatatkan perkawinan mereka dengan berbagai macam alasan dan probematika yang menyebabkan mereka enggan mencatatkan perkawinannya secara hukum positif/hukum Negara dengan kepentingan Negara yang mempunyai tujuan untuk menertibkan Administrasi Perkawinan bagi seluruh Warga Negara Indonesia baik muslim maupun non-muslim, agar mendapatkan perlindungan secara hukum positif/hukum Negara khususnya dalam hal perkawinan. Bukti perlindungan dan pengakuan Negara terhadap peristiwa perkawinan untuk setiap Warga Negara Indonesia adalah Akta Otentik berupa Akta Nikah, dimana dengan adanya Akta Nikah ini, perkawinannya mempunyai kekuatan hukum, dan hak-hak suami istri akan dilindungi oleh Undang-Undang. Seperti yang tertuang dalam Kompilasi Hukum Islam Pasal 6 ayat (2) yang menyebutkan bahwa: "Perkawinan yang dilakukan diluar Pengawasan Pencatat Nikah tidak mempunyai kekuatan hukum." Dan pada Pasal 7 ayat (1) : "Perkawinan hanya dapat dibuktikan dengan Akta Nikah yang dibuat oleh Pegawai Pencatat Nikah."

Perkawinan yang tidak dicatatkan (perkawinan siri) sekarang ini menjadi peristiwa hukum yang cukup memprihatinkan karena tidak hanya dilakukan oleh masyarakat awam/sipil tetapi juga mulai melanda kalangan Pegawai Negeri Sipil (PNS). Dalam hal ini 
penulis membatasi penulisannya hanya dalam Perkawinan Kedua/Ketiga/Keempat Pegawai Negeri Sipil (PNS) Pria yang tidak dicatatkan.

Wanita yang menjadi istri kedua/ketiga/keempat Pegawai Negeri Sipil (PNS) Pria yang tidak dicatatkan harus menerima kenyataan bahwa perikatan perkawinan yang dilakukan adalah perikatan yang lemah. Tidak merupakan perikatan yang sangat kuat (mitssaqan ghalidzan) seperti yang tertuang dalam Kompilasi Hukum Islam Pasal 2. Karena secara hukum Negara tidak mempunyai kekuatan hukum maka istri bisa saja ditinggalkan atau diceraikan secara tiba-tiba, oleh suaminya. Dan pihak istri tidak dapat melakukan perlawanan dan pembelaan seperti apapun dan dia tidak dapat menuntut haknya sebagai istri kepada suaminya. Karena perkawinan yang tidak dicatatkan tidak mempunyai bukti otentik berupa Akta Nikah yang dibuat oleh Petugas Pencatat Nikah. Dalam semua kasus perkawinan yang tidak dicatatkan, pihak wanita selalu menjadi kurban, sementara pihak pria bisa bebas dari jeratan hukum dan mereka dengan melakukan perkawinan siri lagi (tidak dicatatkan).

\subsection{Kedudukan Istri Kedua/Ketiga/Keempat Pegawai Negeri Sipil (PNS) Pria yang Tidak Dicatatkan}

Dalam Syariat agama Islam (figh) syarat sahnya perkawinan adalah:

1. Terpenuhinya semua rukun Nikah;

2. Terpenuhinya semua syarat Nikah;

3. Tidak melanggar larangan perkawinan yang ditentukan dalam syara'.13 Sedangkan rukun perkawinan diantaranya adalah:

4. Adanya calon mempelai pria (calon suami) dan calon mempelai wanita (calon istri);

1. Adanya Wali Nikah;

2. Dua orang saksi;

3. Ijab;

4. Kabul ${ }^{14}$

Meskipun apabila dilihat menurut kacamata hukum Islam, perkawinan yang tidak dicatatkan adalah sah, tetapi karena tidak dicatatkan maka hukum Negara tidak mengakui perkawinan tersebut, sehingga jika dikemudian hari terjadi perceraian atau sesuatu hal yang tidak diinginkan terjadi, hukum Negara tidak dapat melindungi secara penuh. Termasuk jika dikemudian hari terjadi perceraian maka hanya bisa diselesaikan diluar jalur hukum. "Penyelesaian kasus gugatan perkawinan yang tidak dicatatkan hanya bisa diselesaiakan melalui hukum adat."15

Implikasi Yuridis dari perkawinan kedua/ketiga/keempat Pegawai Negeri Sipil (PNS) pria, yang tidak dicatatkan terhadap istri adalah sebagai berikut:

1. Istri tidak dapat menggugat suami, apabila ditinggal dan diceraikan suami secara sepihak;

\footnotetext{
${ }^{13}$ Ibrahim Mayert dan Abdul. Al-Halim, Pengantar Hukum Islam Di Indonesia, (Jakarta, Garuda, 1984), hlm. 333.

${ }^{14}$ Al-Hamdani, Risalah Nikah Hukum Perkawinan Islam, (Jakarta, Pustaka Amini, 1989), hlm.30.

${ }^{15}$ Dikutip dari Ketua Pengadilan Tinggi Agama Semarang, drs. H. Chatib Rasyid, S.H., M.H., sebagai narasumber dalam Seminar, Kajian Yuridis Sosiologis dan Problematika Nikah Siri, Sabtu, 6 Juni 2009, di Gedung Serba Guna Setda, Kabupaten Jepara, Sumber: www.unissula.com.
} 
2. Karena perkawinannya secara hukum Negara dianggap tidak sah maka status istri pun dianggap istri tidak sah, akibatnya suami memiliki kebebasan secara hukum jika kedepannya terjadi konflik dalam perkawinannya;

3. Tidak berhak atas gono gini jika terjadi perceraian;

4. Tidak berhak mewaris jika suami meninggal terlebih dahulu;

5. Jika suami Pegawai Negeri Sipil (PNS) istri tidak mendapatkan tunjangan perkawinan dan tunjangan pensiun suami.16

6. Rentan terhadap Kekerasan Dalam Rumah Tangga (KDRT) baik kekerasan secara fisik, psikis, dan kekerasan seksual dimana istri tidak mendapatkan perlindungan secara hukum seperti yang termaktub dalam Undang-Undang Nomor 23 Tahun 2004 tentang Kekerasan Dalam Rumah Tangga (KDRT).

7. Dampak sosisl dalam bersosialisasi dalam masyarakat istri siri mengalami kesulitan karena dianggap sebagai istri simpanan.

Beberapa alasan mengapa wanita mau dijadikan istri kedua/ketiga/keempat meskipun perkawinannya tidak dicatatkan (perkawinan siri):

a. Adanya pemikiran dalam pemenuhan kebutuhan ekonomi (economic priority);

b. Gaya hidup yang menuntut kita mengikuti trend dunia sekarang;

c. Mencintai suami orang, takut ketahuan istri pertama, perkawinan siri merupakan jalan termudah;

d. Tingginya angka perceraian, berdampak pada bertambahnya wanita-wanita single parent yang membutuhkan pendamping meskipun suami orang;

e. Mencari pendamping yang bisa mengayomi, bisa menjadi imam yang baik, dianggap mampu baik secara fisik maupun secara finansial.

3.3 Kedudukan Anak Dari Perkawinan Kedua/Ketiga/Keempat Pegawai Negeri Sipil yang Tidak Dicatatkan

\subsubsection{Pengertian Anak Sah Menurut Hukum Islam}

Anak/keturunan dalam Islam adalah hubungan kekeluargaan yang bersumber pada pertalian darah, yang terlahir dari perkawinan yang sah. Dengan garis keturunan ayahnya, sehingga anak tersebut menjadi salah seorang anggota keluarga, dimana anak tersebut akan mendapatkan hak-haknya sebagai anak. Menurut hukum Islam yang telah disepakati bersama. Dalam sebagian besar kitab figh bahwa anak sah adalah anak yang lahir dari perkawinan yang sah antara ayah dan ibunya. Dan sahnya seorang anak dalam Islam sangat menentukan nasab/keturunan apakahada atau tidaknya hubungan kebapakan (nasabnya). Para ulama figh berpendapat bahwa para wanita yang bersuami dengan akad yang sah apabila melahirkan maka nasabnya adalah suaminya.

\subsubsection{Pengertian Anak Sah Menurut Hukum Perkawinan Indonesia}

Kedudukan anak menurut Undang-Undang Nomor 1 Tahun 1974 Pasal 42: "Anak yang sah adalah anak yang dilahirkan dalam atau sebagai akibat perkawinan yang sah."

Dalam Kompilasi Hukum Islam (KHI) Pasal 99 huruf a dan b adalah sebagai berikut:

a. “Anak yang terlahir dalam perkawinan yang sah;

b. Hasil perbuatan suami istri yang sah dan dilahirkan oleh istri dalam perkawinan tersebut." 
Anak sah juga diatur pada KUHPerdata Pasal 250, yang mana disebutkan sebagai berikut: "Anak yang dilahirkan atau dibesarkan selama perkawinan, memperoleh suami sebagai bapaknya."

Setelah memaknai pasal-pasal diatas tentang anak sah dapat disimpulkan bahwa pengertian anak sah adalah sebagai berikut:

a. Anak hasil perkawinan dan dilahirkan dalam perkawinan yang sah pula;

b. Anak yang dibenihkan diluar perkawinan tetapi terlahir didalam perkawinan yang sah;

c. Anak yang dibenihkan dalam perkawinan yang sah tetapi terlahir diluar perkawinan;

d. Khusus Kompilasi Hukum Islam anak yang dibenihkan oleh pasangan suami istri dalam perkawinan yang sah tetapi diluar Rahim dan dilahirkan oleh istri. ${ }^{17}$

\subsubsection{Kedudukan Anak Dari Perkawinan Kedua/Ketiga/Keempat Pegawai Negeri Sipil Yang Tidak Dicatatkan}

Anak-anak yang terlahir dalam perkawinan yang tidak dicatatkan dianggap sebagai sebagai anak tidak sah/anak luar kawin. Pernyataan ini ditarik dari pengertian anak sah, merupakan anak hasil dari perkawinan dan dilahirkan dalam perkawinan yang sah. Ini berbanding terbalik dengan anak yang dilahirkan dalam perkawinan yang sah menurut rukun dan syarat sahnya Nikah dalam hukum agama Islam namun tidak dicatatkan pada Petugas Pencatat Nikah dimata hukum Negara perkawinannya tetap dianggap tidak sah, yang mana pada akhirnya ketika perkawinan tersebut menghasilkan anak maka anak tersebut menjadi anak tidak sah atau anak luar kawin. Menurut Undang-Undang Nomor 1 Tahun 1974 Pasal 43 ayat (1) menyatakan bahwa: "Anak yang dilahirkan diluar perkawinan hanya mempunyai hubungan perdata dengan ibunya dan keluarga ibunya." Anak luar kawin ini dapat diakui oleh orang tua biologisnya sehingga ada kemungkinan memiliki hubungan perdata dengan ayah dan ibu kandungnya. Kedudukan anak luar kawin yang telah diakui oleh orang tuanya tidak dapat sederajat dengan anak sah, namun sama-sama memiliki kesempatan untuk menjadi ahli waris dari orang tua biologisnya. Meskipun hak warisnya tidak sebesar ahli waris golongan anak sah. "Anak luar kawin yang diakui akan memiliki hak penuh terhadap harta warisan pada saat pewaris tidak memiliki ahli waris yang selain dari anak luar kawin yang telah diakui." (KUHPerdata Pasal 865).

\subsubsection{Implikasi Yuridis Terhadap Anak Dari Perkawinan Kedua/Ketiga/Keempat Pegawai} Negeri Sipil Yang Tidak Dicatatkan

Ketidak jelasan status hukum anak hasil dari perkawinan yang tidak dicatatkan mengakibatkan hubungan antara ayah dan anak menjadi tidak kuat, sehingga ayahnya dapat menyangkal bahwa anak tersebut bukan anak kandungnya. Permohonan Akta Kelahiran yang diajukan kepada Kantor Catatan Sipil bila tidak dapat menunjukkan Akta Nikah orang tua anak tersebut. Maka dalam Akta Kelahiran anak tersebut diatas statusnya dianggap sebagai anak luar kawin, dan tidak tertulis nama ayah kandungnya dan hanya

${ }^{17}$ D. Y. Witanto, S.H., Hukum Keluarga Hak Dan Kedudukan Anak Luar Kawin Paska Keluarnya Putusan MK Tentang Uji Materiil UU Perkawinan (Jakarta, Prestasi Pustakarya, Juni 2012), hlm.39. 
tertulis bu kandungnya saja. Anak Luar Kawin tidak berhak menuntut nafkah dari orang tua biologisnya, biaya pendidikan, maupun warisan dari ayahnya. Anak luar kawin tidak berhak untuk mewaris dari harta ayah kandungnya, kecuali anak luar kawin tersebut diakui oleh ayah biologisnya. Jika anak luar kawin ini berjenis kelamin perempuan yang hendak melangsungkan perkawinan maka wali nikah yang bersangkutan adalah wali hakim. Anak luar kawin yang tidak diakui ayahnya dan keluarga ayahnya akan semakin terpuruk nasibnya karena semua pendukung hidupnya akan terputus termasuk nafkah lahir untuk anak tersebut. Apalagi jika terjadi perceraian, maka semua hak ibu dan anaknya tidak bisa didapatkan kecuali secara suka rela suami atau ayah biologis anak tersebut memberikan nafkah lahir dan sebagian hartanya. Dalam pergaulan pun anak luar kawin menjadi lebih rendah diri karena status hukumnya yang tidak jelas.

\section{Perlindungan Hukum Terhadap Istri Dan Anak Hasil Perkawinan Kedua/Ketiga/Keempat Pegawai Negeri Sipil Yang Tidak Dicatatkan}

\subsection{Perlindungan Hukum Terhadap Istri Kedua/Ketiga/Keempat Pegawai Negeri Sipil Yang Tidak Dicatatkan}

Perlindungan hukum terhadap istri kedua/ketiga/keempat khususnya istri dari Pegawai Negeri Sipil (PNS) pria yang tidak dicatatkan memang sangatlah lemah. Namun tidak perlu berkecil hati, pemecahan masalah tersebut diatas dewasa ini dapat disikapi dengan cara mengajukan permohonan Itsbat Nikah Poligami kepada Pengadilan Agama. Itsbat Nikah ke Pengadilan Agama oleh para pemohon dijadikan alas hukum untuk mencatatkan perkawinannya kepada Pegawai Pencatat Nikah pada Kantor Urusan Agama (KUA) Kecamatan, Kantor Urusan Agama (KUA) Kecamatan akan mengeluarkan Buku Kutipan Akta Nikah sebagai bukti otentik bahwa suatu perkawinan telah tercatat. Seperti yang tertuang didalam Kompilasi Hukum Islam Pasal 7 ayat (3) huruf a-e. Dibawah ini:

a. Adanya perkawinan dalam rangka penyelesaian perceraian;

b. Hilangnya Akta Nikah;

c. Adanya keraguan tentang sah atau tidaknya salah satu syarat perkawinan;

d. Adanya perkawinan yang terjadi sebelum berlakunya Undang-Undang No. 1 Tahun 1974;

e. Perkawinan yang dilakukan oleh mereka yang tidak mempunyai halangan perkawinan menurut Undang-Undang No. 1 Tahun 1974. Namun tetap dalam hal ini Hakim berperan penuh dalam menilai pengajuan perkara Itsbat Nikah istri poligami, Hakim harus membuat interpretasi yang arif, apakah perkara tersebut diajukan dari awal perkara sebagai izin poligami. Ada sisi negatif maupun sisi positif dari Itsbat Nikah ini, sisi negatifnya dimungkinkan adanya penyelundupan perkara dimana dalam mengajukan permohonan Itsbat Nikah tanpa melibatkan istri pertama atau istri terdahulu. Namun sisi positifnya, akhirnya status perkawinannya menjadi sah di mata hukum Negara dengan demikian akibat hukum yang ditimbulkan pun menjadi terlindungi secara hukum Negara. Dengan memperhatikan nasib anak-anak yang lahir dari perkawinan yang tidak dicatatkan (perkawinan siri) dan satu-satunya jalan dengan menempuh Itsbat Nikah di Pengadilan Agama statu anak pun berubah menjadi anak sah juga. Hakim dalam menetapkan perkara Itsbat Nikah poligami, 
Hakim dalam memutuskan perkara harus memperhatikan semua hal secara objektif dengan pertimbangan yang matang. Setiap perkawinan harus dicatatkan menurut perundang-undangan yang berlaku untuk mewujudkan ketertiban administrasi dalam Perkawinan Indonesia. Sementara untuk perkawinan yang sudah terlanjur melakukan nikah siri maka perkawinan tersebut harus disahkan dengan mengajukan Itsbat Nikah di Pengadilan Agama. Persetujuan dari istri pertama/terdahulu dalam Itsbat Nikah pada istri poligami bukanlah suatu keharusan, jika persetujuan tidak mungkin didapatkan, hakim dengan pertimbangan tertentu dapat mengabulkan perkara Itsbat Nikah istri poligami.

\subsection{Perlindungan Hukum Terhadap Anak Hasil Perkawinan Kedua/Ketiga/Keempat Pegawai Negeri Sipil Yang Tidak Dicatatkan}

Perkawinan yang sah adalah sah menurut hukum agama dan hukum Negara (perkawinan yang dicatatkan), begitu pula sebaliknya perkawinan yang hanya dilakukan menurut rukun dan syarat sahnya nikah secara hukum Islam tetapi tidak dicatatkan, menjadi tidak sah secara hukum Negara dan mirisnya lagi perkawinan tersebut dianggap tidak pernah ada. Dan ketika dari perkawinan yang tidak dicatatkan tersebut menghasilkan keturunan maka status anak tersebut menjadi anak tidak sah/ anak luar kawin. Dalam Undang-Undang Nomor 1 Tahun 1974 Tentang Perkawinan Pasal 42, menyatakan bahwa "Anak sah adalah anak yang dilahirkan dalam atau sebagai akibat perkawinan yang sah pula." Sedangkan pada Pasal 43 Undang-Undang Nomor 1 Tahun 1974 menyatakan bahwa: "Anak yang dilahirkan diluar perkawinan hanya mempunyai hubungan perdata dengan ibunya dan keluarga ibunya saja."

Berdasarkan Putusan MK Nomor 46/PUU-VIII/2010, terhadap permasalahan anak luar kawin. Diakui maupun tidak, lahirnya Putusan Mahkamah Konstitusi atas permohonan uji materiil (judificial review) yang diajukan oleh $\mathrm{Hj}$. Aisyah Mochtar alias Machica binti $\mathrm{H}$. Mochtar Ibrahim dan Muhammmad Iqbal Ramadhan bin Moerdiono telah membawa paradigma baru pada sistem hukum perdata dan hukum keluarga di Indonesia, banyak pro dan kontra mengiringi lahirnya putusan ini. Sebagian pendapat menyatakan bahwa putusan ini memberikan perlindungan hak-hak anak dimata hukum dan masyarakat, sedangkan pendapat lain mengatakan bahwa dengan putusan tersebut diatas akan menimbulkan permasalahan baru menyangkut hukum waris yang berlaku di Indonesia. Terlepas dari pendapat pro dan kontra yang berkembang dalam masyarakat tersebut diatas, ini dikarenakan pada kenyataannya yang terjadi selama ini anak yang lahir di dalam perkawinan secara syara' agama namun tidak dicatatkan/perkawinan siri, hukum sama sekali tidak dapat memberikan rasa keadilan bagi setiap warga Negaranya yang menurut konstitusi harusnya setiap warga Negara diperlakukan sama dihadapan hukum. Pemohon dan anaknya mempunyai hak konstitusional untuk mendapatkan pengesahan atas perkawinan dan status hukum anaknya. Perkawinan pemohon adalah sah dank arena telah memenuhi rukun nikah secara Islam. Dalam Pasal 28B ayat (1) Undang-Undang Dasar 1945 menyatakan bahwa: "Setiap orang berhak untuk membentuk keluarga dan melanjutkan keturunan melalui perkawinan yang sah." Pasal 28B ayat (2): “Setiap anak berhak atas kelangsungan hidup, tumbuh, dan berkembang serta berhak atas perlindungan dari kekerasan dan diskriminasi." Serta pada Pasal 28D ayat (1) Undang-Undang Dasar 1945 
yang menyatakan bahwa: "Setiap orang berhak atas pengakuan, jaminan, perlindungan, dan kepastian hukum yang adil serta pengakuan yang sama dihadapan hukum." Setelah ditelaah lebih dalam bahwa terjadi pelanggaran atas hak konstitusional dengan berlakunya Undang-Undang Nomor 1 Tahun 1974 tentang perkawinan, khususnya Pasal 2 ayat (2) dan Pasal 43 ayat (1), yaitu berkaitan dengan pencatatan perkawinan dan hubungan hukum anak yang dilahirkan dari perkawinan yang tidak dicatatkan. Dan telah terjadi pelanggaran atas hak konstitusional Pemohon sebagai Warga Negara Indonesia, karena Pasal 2 ayat (2) dan Pasal 43 ayat (1) Undang-Undang Nomor 1 Tahun 1974 tentang perkawinan tersebut bertentangan dengan Pasal 28B ayat (1) dan ayat (2) serta Pasal 28D ayat (1) UndangUndang Dasar 1945.Yang mengakibatkan perkawinan Pemohon yang telah dilakukan secara sah sesuai agama yang dianut tidak mendapatkan kepastian hukum sehingga berimbas pada anak hasil perkawinan tersebut juga tidak mendapatkan kepastian hukum pula. Tidak ada seorang anak pun yang ingin dilahirkan di muka bumi ini dipersalahkan dan didiskriminatifkan karena cara perkawinan yang dilakukan kedua orang tuanya tidak dicatatkan yang dianggap tidak sah secara hukum Negara tetapi tetap sah secara hukum agama. Akhirnya dengan Putusan Mahkamah Konstitusi Nomor 46/PUU-VII/2010 menyatakan bahwa "Anak yang dilahirkan diluar perkawinan mempunyai hubungan perdata dengan ibunya dan keluarga ibunya seta dengan laki-laki sebagai ayahnya yang dapat dibuktikan berdasarkan ilmu pengetahuan dan tekhnologi dan/atau alat bukti lain menurut hukum mempunyai hubungan darah, termasuk hubungan perdata dengan keluarga ayahnya." Yang pada akhirnya hak-hak anak luar kawin dapat dilindungi secara hukum dan perundang-undangan.

\section{PENUTUP}

Implikasi Yuridis terhadap istri dari perkawinan kedua/ketiga/keempat Pegawai Negeri Sipil (PNS) Pria yang tidak dicatatkan ditinjau dari Undang-Undang Nomor 1 Tahun 1974 dan PP Nomor 45 Tahun 1990 juncto PP Nomor 10 Tahun 1983 bahwasanya perkawinan yang tidak dicatatkan akan menyebabkan timbulnya akibat hukum yang merugikan di pihak istri dan anak yang akan dilahirkan dalam perkawinan tersebut. Status istri tidak kuat secara $\mathrm{h}$ Implikasi Yuridis terhadap anak dari perkawinan keduaketiga/keempat Pegawai Negeri Sipil (PNS) Pria yang tidak dicatatkan.

Perkawinan yang sah menurut rukun dan syarat agama tetapi tidak dicatatkan tetap dianggap perkawinan yang tidak sah dimata hukum Negara Indonesia, yang pada akhirnya anak yang dilahirkan dalam perkawinan tersebut juga menjadi anak tidak sah/anak luar kawin. Dalam UUP Nomor 1 Tahun 1974 Pasal 43 ayat (1) “Anak yang dilahirkan diluar perkawinan hanya mempunyai hubungan perdata dengan ibunya dan keluarga ibunya saja" dari bunyi Pasal tersebut, dapat di tarik kesimpulan bahwa anak luar kawin tidak memiliki hubungan keperdataan sama sekali dengan laki-laki sebagai suami dan ayah biologis anak tersebut serta keluarga ayahnya. Jadi rentan sekali terhadap pengingkaran pengakuan terhadap anak luar kawin, yang pada akhirnya anak luar kawin tidak mempunyai hak mendapat pengakuan dari ayah biologisnya, tidak berhak atas nafkah, tidak mempunyai hak untuk mewaris jika ayahnya meninggal dunia terlebih dahulu, merasa rendah diri dilingkungan karena menyandang status anak luar kawin; tidak dapat 
menuntut kepada ayah biologisnya untuk mendapatkan pendidikan yang layak. Banyak sekali dampak negatif yang didapatkan dari anak luar kawin dan ini tentunya akan mempengaruhi secara psikologis anak kedepannya.

Perlindungan hukum terhadap istri kedua/ketiga/keempat Pegawai Negeri Sipil Pria yang tidak dicatatkan satu-satunya jalan adalah mengajukan permohonan Izin Itsbat Nikah Poligami meskipun tanpa persetujuan dari istri pertama atau terdahulu agar Majelis Hakim melihat, menganalisa, menimbang, memutuskan apa yang menjadi putusan hakim hendaknya dapat mewujudkan bagi kematsalahatan bersama. Dengan dikabulkannya Itsbat Nikah Poligami maka kedudukan istri kedua/ketiga/keempat menjadi istri yang sah secara syara' agama dan sah pula secara hukum Negara, maka semua hak dan kewajiban suami istri akanmendapatkan perlindungan yang utuh dari perundang-undangan yang berlaku pada hukum Negara Indonesia.

Perlindungan hukum terhadap anak hasil perkawinan kedua/ketiga/keempat Pegawai Negeri Sipil (PNS) Pria yang tidak dicatatkan. Dengan dikabulkannya permohonan orang tua perihal Itsbat Nikah Poligami maka status perkawinannya menjadi sah begitu pula anak yang terlahir dari perkawinan yang tidak dicatatkan tersebut berubah status menjadi anak sah bukan lagi anak luar kawin. Yang pada akhirnya berimbas pada hak-hak anak yang harus dipenuhi oleh orang tua khususnya ayah akan terwujud dan mendapat perlindungan dari hukum Negara. Anak dapat memiliki Akta Kelahiran, karena orang tua memiliki Akta Perkawinan, anak mendapat hak mewaris jika ayahnya meninggal dunia, anak berhak mendapatkan kehidupan yang sejahtera lahir dan batin, layak mendapatkan pendidikan yang layak pula. 


\section{DAFTAR PUSTAKA}

D.Y. Witanto. Hukum Keluarga Hak Dan Kedudukan Anak Luar Kawin Paska Keluarnya Putusan MK Tentang Uji Materiil Undang-Undang Perkawinan. Jakarta: Prestasi Pustakarya, Juni 2002.

Grahamedia Press, Undang-Undang Republik Indonesia Nomor 1 Tahun 1974

Tentang Perkawinan, (Jakarta, Grahamedia Press, 2014), hlm.2, 120-121.

Yusuf Al Qadhawi. Halal dan Haram Dalam Islam. Surabaya: Bina Ilmu, 1976.

\section{Peraturan Perundang-undangan}

Undang-Undang Nomor 1 Tahun 1974 tentang Perkawinan

Undang-Undang Nomor 23 Tahun 2004 tentang Kekerasan Dalam Rumah Tangga

PP Nomor 10 Tahun 1983 tentang Izin Perkawinan dan Perceraian Bagi Pegawai Negeri Sipil (PNS)

PP Nomor 45 Tahun 1990 Perubahan Atas PP Nomor 10 Tahun 1983 tentang Izin Perkawinan dan Perceraian Bagi Pegawai Negeri Sipil (PNS)

Undang-Undang Nomor 53 ahun 2010 Perubahan Atas PP Nomor 30 Tahun 1980 tentang Peraturan Disiplin Pegawai Negeri Sipil

Undang-Undang Nomor 43 Tahun 1999 Perubahan Atas PP Nomor 8 Tahun 1974 tentang Pokok-Pokok Kepegawaian

Putusan Mahkamah Konstitusi Nomor 46/PUU-VII/ 2010 